\title{
Structural Equation Modeling for Investigating the Factors Affecting the Faculty Members Adoption and Use of E-Learning Platform in Academic Purposes: An Empirical Validation in Higher Educational Context
}

\author{
Hitesh Choudhury $^{1}$ and Guruprasad Khataniar ${ }^{2}$ \\ ${ }^{1}$ Research Scholar, ${ }^{2}$ Ex. Controller of Examination, \\ Krishna Kanta Handique State Open University, Assam, India \\ E-Mail: hitesh_ch01@rediffmail.com, drkhataniar@gmail.com
}

\begin{abstract}
E-learning Platform is one of the most flexible and important innovations for delivering education in modern educational system. However successful implementation of the E-learning Platform (ELP) depends on the users behavioral intension of adoption. Most of the Higher educational institutions in North-East Indian region is using Information and Communication Technology in teaching and learning process and moving towards the adoption of ELP. In this paper the main focus is to examine the factors affecting the faculty members perception and adoption of E-learning platform in academic purposes. In the theoretical framework of this study Technology Acceptance Model (TAM) is used to analyze the perception and behavioral intension of faculty members adoption and use of E-learning platform in academic purposes. The theoretical framework is proposed that includes the core construct of TAM namely Perceived Usefulness, Perceived Ease of Use, Attitudes towards using together with two external variables namely E-learning Self Efficacy and Job Relevance. The data were collected from 81 full time/part time faculty members of randomly selected University/Colleges in North East Indian region through a self-designed questionnaire comprising 21 items that represent the above mentioned six constructs. The data were used to validate and hypothesized research model. The data analysis was performed through structural equation modeling (SEM) by using the software package SPSS version 16 together with STATA. The study reveals that the adoption and using E-learning platform mainly depends on the behavioral intention and attitude towards using the platform. Perceived usefulness and job relevance are the most strongest and important predictors of behavioral intention and attitude towards using E-learning platform in academic purposes.

Keywords: Structural Equation, E-learning Platform, Technology Acceptance Model, Perceived Usefulness, Perceived Ease of Use, Attitudes towards using, E-learning Self-efficacy
\end{abstract}

\section{INTRODUCTION}

The advancement of Information and Communication technology and rapid growth of internet technology has given a new dimension to transform educational programs in universities/Colleges. Through this transformation, most of the universities/Colleges across the globe are promoting online courses to increase communication with students and to reduce the time and space constraints that are associated with traditional education [1]. E-learning Platform is one of the most recent used E-learning tool in
Universities/Colleges to facilitates their teaching and learning process. It has shaped new ways of transforming information between teachers and students to improve the academic and technology related performance of both students and teachers [2]. These types of platform support various types of communication, production and development tools namely course creation, discussion forum, file sharing, online chatting, online exam, instructor scheduling posting online grade, submitting online assignment, announcements of course plans etc. However successful implementation of this E-learning platform depends on the behavioral intention and attitude of faculty members, instructors, students and university/college support system. Among all these faculty members and instructors play a central role in the adoption and implementation of a new technological system to facilitate their teaching and learning process [3][4]. Besides these when a new E-learning system is implemented in its domain it needs to be adopted by its users but users attitude and perceptions regarding the acceptance and use of the system can be affected by some system characteristics namely system reliability, system efficiency, system security etc. and some users individual factors namely users age, users E-learning experience, users job relevance etc.[5].

Understanding the faculty member's attitude and behavioral intention to adoption and use of e-learning platform in the academic purposes is a prime issue. So the main objectives of this study are to understand the factors that affect the faculty members attitude and behavioral intention to adopt and use E-learning Platform in academic purposes. To understand the factors that affect the faculty members attitude and behavioral intention to adopt and use E-learning Platform in their academic purposes, the technology acceptance model (TAM) is used. We hypothesized the relationship between the original TAM construct and two external variables viz. Job relevance and E-learning selfefficacy and were empirically tested using the structural equation modeling (SEM) approach.

This paper has been organized as follows: A brief introduction has been given at the beginning of the paper. Secondly, after a brief introduction, the proposed research model and the casual hypothesis are formulated. Thirdly, 
the preparation of the survey instrument, procedure of data collection and research participation has been given. Fourthly, the research model has been explored for reliability and validity and exploratory factor analysis has been conducted to identify the factor structure of the measurement item of the model. In section fifth, for the measurement and structural model, the fit indices has been verified. In addition for structural model, the formulated hypotheses have been analyzed. Lastly, concludes this paper with implications and limitations of the study.

\section{PROPOSED RESEARCH MODEL AND HYPOTHESIS FORMULATION}

Most of the researchers use Technology Acceptance Model (TAM) initially developed by Davis, to examine the user's acceptance or adoption a new information system (IS). Davis first introduced the TAM in his Ph.D. thesis in the year 1986 which was an extension of Theory of Action (TRA). After three years later i.e. in the year 1989 Davis created TAM to develop and validates new scales for two specific constructs namely Perceived Usefulness (PU) and Perceived Ease of Use (PEOU) by considering these two as the fundamental determinants to explain why user accept or reject a new information system that means users attitude towards using the new information system. After that, time to time the researchers added some new constructs or some external variables to the original TAM to test the relationship between them. Gefenand Straus (1997) had added the variable "Gender" to the original TAM to see that perceived attitude of E-mail can differ with Gender. They established that woman use of E-mail is higher than Man [6]. "Perceived Risk” is another external variable added to TAM by Featherman (2001). In his investigation he had found that perceived Risk is another factor of the individual intension to adoption of internet- based e-payment system by using e-billpay software. He had performed the research to better understand the consumer evaluation and adoption intention of an internet-based Information System (IS) during conditions of uncertainty and Perceived Risk [7]. Gefenand Detmar (2003) had added another variable "Perceived Trust" to show that consumer trust is an important factor to widely accepted online commerce. The study also provides that online trust is built through mainly a belief that the vendor has nothing to gain and a belief that there are safety mechanism built into website [8]. In 2006, Lee et al., has added the variable "Social Influence" to the TAM to show that the Social influence has a positive influence on the technology acceptance behavior of a person [9]. In many studies relationship were found among these constructs. Lim, (2012), in their studies had found that consumers Perceived Usefulness and Perceived Ease of Use have a significant relationship with attitudes towards online shopping [10]. We also adopted all the construct PU, PEOU and ATU from earlier studies but the items related to these construct are re-worded to make them relevant to the specific context of this study.

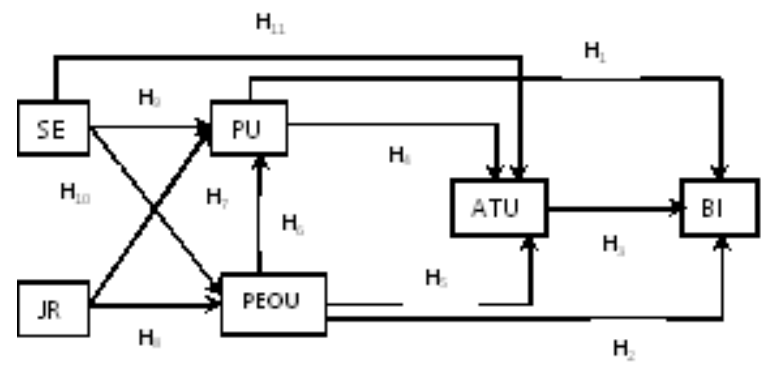

Fig. 1 Proposed Research Model

\section{A. Perceived Usefulness (PU)}

The term Perceived Usefulness has been used by different researchers in their different research areas. Perceived usefulness defined by Davis (1989) as "The degree to which a person believes that using a particular system would enhance his/her job performance". People tend to use or not to use a system to the extent they believe it will help them to perform their job better[3]. That means perceived usefulness is the usefulness or benefit by using any system that can enhance the performance of the person that they using it. Lee and Lee (2011), defined the term Perceived Usefulness as user's belief that using the technology will improve their job performance [11]. Mirabda et al. (2016) defined Perceived usefulness as the extent to which an individual believes that using the Information System (IS) will enhance their productivity [12]. From faculty members point of view Perceived Usefulness may influence their behavioral intension to adopt E-learning platform. So, the following hypothesis is formulated.

H1: Faculty members Perceived Usefulness (PU) of Elearning Platform will positively influence towards the behavioral intension to adopt the platform in academic purposes.

It is expected that the faculty members who perceive Eearning Platform as useful will influence their intension to adopt the platform in academic purposes.

\section{B. Perceived Ease of Use (PEOU)}

Technology Acceptance Model has been widely used by different researchers to predict users acceptance and use a particular system is mainly based on Perceived Ease of Use of the system. Davis (1989), define the term "Perceived Ease of Use as the degree to which a person believes that using a particular system would be free of effort [3]. Vankatesh and Davis (1996) has established in their research that, Computer Self-efficacy and Objective Usability of a user is determine his or her perception of ease of use of the specific system [13]. From faculty members point of view Perceived Ease of Use may influence their intension to adopt E-learning Platform. So the following hypothesis is formulated. 
Structural Equation Modeling for Investigating the Factors Affecting the Faculty Members Adoption and Use of E-Learning Platform in Academic Purposes: An Empirical Validation in Higher Educational Context

H2: Faculty members Perceived Ease of Use (PEOU) of Elearning platform will positively influence on their behavioral intension to adopt the platform in academic purposes.

It is expected that the teachers who perceive E-learning platform to be easy to use will positive influence their adoption the E-learning platform in academic purposes.

\section{Attitudes towards using a technology (ATU)}

The term attitudes have defined by different persons at different times in different ways. Schafer and Tait( 1986), define the attitudes as a bundle of feelings and tendencies ( It may be positive or negative) that are influence by a person's decision towards a person or an item [14]. In TAM terminology it can be define person's positive or negative feelings towards a new Information System (IS) for accepting or rejecting it. The attitudes of a person towards a new technology is determined of the persons perceptions, believes and ideas of that technology. It occupies a core place in the analysis of the behavior of the user [11]. According to Albirini, A., (2006), that the successful implementation of a new technology in educational programs mainly depends on the attitudes of the faculty members involved. Among faculty members who hold the positive attitudes towards the technology feel comfortable using that technology and are ready to overcome the obstacles arises [12]. So, on the basis of these we have formulated the following hypothesis:

H3: The attitudes towards Using(ATU) E-learning Platform will have a positive effect on the faculty member's behavioral intention to adopt and use E-learning Platform for academic purposes.

D. Relation between Perceived Usefulness, Perceived Ease of Use and Attitude towards using E-learning Platform in academic purposes:

The Construct Perceived Usefulness and Perceived Ease of Use predicts the attitudes of users towards a new system [13].Chang et al.,(2012) in their research paper theorized that the Perceived Ease of Use as a direct determinant of Attitude towards Using Mobile technology for college students [14]. So, the following three hypotheses are formulated:

H4: Faculty members Perceived Usefulness (PU) of Eearning Platform will positively influence on Attitudes towards use (ATU) of E-learning platform for academic purposes.

H5: Faculty members Perceived Ease of Use (PEOU) of Elearning platform will positively influence on Attitudes towards use (ATU) of E-learning platform for academic purposes.

H6: Faculty members Perceived Ease of Use (PEOU) of Elearning platform will positively influence on the Perceived Usefulness (PU) of the E-learning Platform.

\section{E. External variables related to the core constructs of TAM}

The constructs PU, PEOU, ATU are the necessary factors but may not be sufficient of intention to adopt and use Elearning Platform, so some other external variables may also be needed [15]. Thus, after reviewing the relevant studies, we can consider two other external variables namely job relevance(JR) and E-learning self-efficacy(SE) to study the relationship with the original TAM Constructs. The researchers believe that the suggested external variables moderate the original TAM variables. The following explains the hypotheses on the relationship between external variables and TAM variables.

Job relevance is considered as a core component in matching process which reflects a user's judge that effect of using a particular system on his/her job [16]. Venkatesh and Davis (2000), define it as the individual's perception regarding the degree to which the target system is applicable to his/her job [17].So, we formulated the following two hypothesis:

H7: Job relevance (JR) will positively influence the PU of adopting and using E-learning Platform in academic purposes

H8: Job relevance (JR) will positively influence the PEOU of using E-learning Platform in academic purposes

Bandura (1994) defines self-efficacy as the beliefs of one's capabilities or the level of confidence to organize and to perform a particular task, activity and action [18]. In case of E-learning, Fathema et. al,(2015) define the perceived selfefficacy as the user's judgment or belief or the confidence of his/her own capacity of operating/ navigating/ working with the E-learning system. Users with higher perceived self-efficacy have stronger perceptions of perceived ease of use (PEOU) and perceived usefulness (PU) of the system [19]. It is a situation-specific form of efficacy that refers to the individual's judgment on their capability to use the online learning system [20]. In this connection we formulated the following three hypothesis:

H9: The faculty members E-learning Self-efficacy (SE) has positive influence on PU of adopting and using E-learning Platform in academic purposes.

H10: The faculty members E-learning Self-efficacy (SE) has positive influence on PEOU of adopting and using Elearning Platform in academic purposes.

H11: The teachers E-learning Self-efficacy (SE) have positive influence on ATU of using E-learning Platform in academic purposes.

\section{RESEARCH METHOD}

\section{A. Data Collection}

The main instruments used in this study was a selfadministered questionnaire based on the comprehensive 
prior literature review that consisting 21 items measuring 6 construct to build a measurement model that to construct a structural model. Among all construct, four of them are from Original TAM construct namely PU, PEOU, ATU, BI and the remaining two are external variables namely JR and SE. Among 21 measuring items, 14 items has been taken from previous studies and remaining 7 items are selfdeveloped. Each of the measurement items were coded by a unique code for analyzing the model and each measurement items were attached to a latent construct. All the items were measured in a 5 point Likert-Scale labelled as 5 for strongly agree, 4 for agree, 3 for neutral, 2 for disagree and 1 for strongly disagree.

\section{B. Participants}

The participants of the present study were 81 full time/part time faculty members, Instructors working at different Colleges/Universities and other higher educational institutions in North-East Indian region from different disciplines. We targeted those portion of the faculty members/instructors which are familiar partially or fully any one of E-learning platform.

TABLE I ITEMS FOR MEASURING THE CONSTRUCTS

\begin{tabular}{|c|c|c|}
\hline \multicolumn{3}{|c|}{ Section I : Perceived Usefulness(PU) } \\
\hline $\begin{array}{l}\text { Item } \\
\text { Code }\end{array}$ & Item & References \\
\hline PU1 & I think that using E-learning Platform would improve my performance in my Job & Alharbi and Drew (2014)[32] \\
\hline PU2 & $\begin{array}{l}\text { I think that using E-learning platform would enable me to accomplished task more quickly in } \\
\text { my Job }\end{array}$ & Alharbi and Drew (2014)[32] \\
\hline PU3 & $\begin{array}{l}\text { I think that using E-learning platform will help me to become more independent as a } \\
\text { academician/learner }\end{array}$ & Self-developed \\
\hline PU4 & I think that using E-learning platform would make it easier to do my Job & Alharbi and Drew (2014)[32] \\
\hline \multicolumn{3}{|c|}{ Section II : Perceived Ease of Use (PEOU) } \\
\hline PEOU1 & I think that eLearning platform is easy to use & Davis (1989)[3] \\
\hline PEOU2 & I think that it would be easy for me to become a skillful using E-learning Platform & Davis (1989)[3] \\
\hline PEOU3 & I think that Using E-learning Platform will be flexible to interact with the students & Self-developed \\
\hline PEOU4 & I think that learning to operate E-learning platform would be easy for me & Alharbi and Drew (2014)[32] \\
\hline \multicolumn{3}{|c|}{ Section III : Attitude Towards Using (ATU) } \\
\hline ATU1 & I think that using E-learning platform makes learning more interesting & Alharbi and Drew (2014)[32] \\
\hline ATU2 & $\begin{array}{l}\text { I think that it is a good idea to use E-learning platform to facilitate teaching and learning } \\
\text { process }\end{array}$ & Self-developed \\
\hline ATU3 & I think that teaching and learning through E-learning platform is more pleasurable & Self-developed \\
\hline ATU4 & I have generally favourable attitude towards using E-learning Platform in academic purposes & Self-developed \\
\hline \multicolumn{3}{|c|}{ Section-IV : E-learning Self Efficacy (SE) } \\
\hline SE1 & $\begin{array}{l}\text { I will definitely feel confident finding information by using E-learning Platform in academic } \\
\text { purposes }\end{array}$ & Park (2009)[21] \\
\hline SE2 & I have the necessary skills to using E-learning platform & Park (2009)[21] \\
\hline SE3 & I think that I can use E-learning Platform without support & Self-developed \\
\hline \multicolumn{3}{|c|}{ Section V : Job Relevance (JR) } \\
\hline JR1 & I think that in my Job, the usage of E-learning platform is important & $\begin{array}{c}\text { Venkateshand } \\
\text { Davis(2000)[17] }\end{array}$ \\
\hline JR2 & I think that in my Job, uses of E-learning platform is relevance & $\begin{array}{l}\text { Venkatesh and Davis } \\
(2000)[17]\end{array}$ \\
\hline JR3 & $\begin{array}{l}\text { I think that Using E-learning platform can significant increase the quality of output of my } \\
\text { Job }\end{array}$ & Self- developed \\
\hline \multicolumn{3}{|c|}{ Section VI : Behavioral Intention (BI) } \\
\hline BI1 & I have plan to use E-learning Platform in future in my academic purposes & Maduku (2014)[22] \\
\hline $\mathrm{BI} 2$ & If possible, I will try to use E-learning platform in academic purposes & Taylor and Tood (1995)[23] \\
\hline $\mathrm{BI} 3$ & I will try to use E-learning platform if necessary in my work in academic purposes & Taylor and Tood (1995)[23] \\
\hline
\end{tabular}




\section{MEASUREMENT OF RELIABILITY AND VALIDITY}

A model is considered fit for model testing if it is reliable and valid. So reliability and validating of measures and their convergent and discriminant validity were checked to developed survey instrument. Fornel \& Larker (1981)[24] had recommended three criterion for convergent validity: the factor loading for individual item should be more than 0.50; The composite reliability(CR) for each construct should be more than 0.70 and the average variance extracted(AVE) should be greater than 0.50. It shown in tableII, each item had a loading factor ranges from 0.63 to 0.89 and all are greater than 0.50 . CR value ranges from 0.71 to 0.89 which are above 0.70 and AVE ranges from 0.53 to 0.74 and all are $\geq 0.50$. All these values meet the recommended value and hence the convergent validity of the model is verified. The factor loading of each item was measured by using STATA.

\begin{tabular}{|c|c|c|c|c|c|}
\hline Constructs & Items & $\begin{array}{c}\text { Standardized Factor } \\
\text { Loading }\end{array}$ & Cronbach's $\alpha$ & CR & AVE \\
\hline \multirow{4}{*}{ PU } & PU1 & 0.83 & \multirow{4}{*}{0.86} & \multirow{4}{*}{0.86} & \multirow{4}{*}{0.60} \\
\hline & PU2 & 0.67 & & & \\
\hline & PU3 & 0.70 & & & \\
\hline & PU4 & 0.89 & & & \\
\hline \multirow{4}{*}{ PEOU } & PEOU1 & 0.83 & \multirow{4}{*}{0.85} & \multirow{4}{*}{0.87} & \multirow{4}{*}{0.59} \\
\hline & PEOU2 & 0.76 & & & \\
\hline & PEOU3 & 0.68 & & & \\
\hline & PEOU4 & 0.79 & & & \\
\hline \multirow{4}{*}{ ATU } & ATU1 & 0.68 & \multirow{4}{*}{0.78} & \multirow{4}{*}{0.89} & \multirow{4}{*}{0.53} \\
\hline & ATU2 & 0.68 & & & \\
\hline & ATU3 & 0.68 & & & \\
\hline & ATU4 & 0.63 & & & \\
\hline \multirow{3}{*}{ BI } & BI1 & 0.88 & \multirow{3}{*}{0.91} & \multirow{3}{*}{0.80} & \multirow{3}{*}{0.74} \\
\hline & $\mathrm{BI} 2$ & 0.86 & & & \\
\hline & BI3 & 0.87 & & & \\
\hline \multirow{3}{*}{ SE } & SE1 & 0.65 & \multirow{3}{*}{0.80} & \multirow{3}{*}{0.71} & \multirow{3}{*}{0.58} \\
\hline & SE2 & 0.81 & & & \\
\hline & SE3 & 0.82 & & & \\
\hline \multirow{3}{*}{ JR } & JR1 & 0.82 & \multirow{3}{*}{0.87} & \multirow{3}{*}{0.81} & \multirow{3}{*}{0.68} \\
\hline & JR2 & 0.83 & & & \\
\hline & JR3 & 0.83 & & & \\
\hline
\end{tabular}

The reliability analysis measures the internal consistency of items for each construct. Cronbach's $\alpha$ are calculated by using SPSS verson 16 to measure the inter-item consistency for each construct. That means how closely related the set of items representing the construct. According to Schmitt, a scale is considered to be reliable when Cronbach's $\alpha$ value greater than 0.70 [25]. As shown in Table II, the Cronbach's $\alpha$ value for six constructs ranges from 0.78 to 0.91 indicating that all the measures employed in this study demonstrates a high satisfactory internal consistency and therefore the survey are considered as reliable instruments

According to Fornell and Larcker [24], Discriminant validity measures the distinctness of construct from each other and it can be assessed by comparing the square root of the average variance extracted (AVE) for a given construct with inter-construct correlation. If the value of square root of Average variance extracted is higher than the interconstruct correlation then discriminant validity will met. In table III the diagonal values are the square root of AVE which are higher than the values of inter-construct correlations i. e the values of their corresponding rows and columns and indicates a good level of discriminant validity of the measurement model.

TABLE III DISCRIMINANT VALIDITY ANALYSIS

\begin{tabular}{|c|c|c|c|c|c|c|}
\hline Construct & PU & PEOU & ATU & BI & SE & JR \\
\hline PU & 0.84 & & & & & \\
\hline PEOU & 0.72 & 0.82 & & & & \\
\hline ATU & 0.51 & 0.37 & 0.81 & & & \\
\hline BI & 0.49 & 0.49 & 0.37 & 0.80 & & \\
\hline SE & 0.60 & 0.46 & 0.36 & 0.48 & 0.71 & \\
\hline JR & 0.43 & 0.45 & 0.33 & 0.66 & 0.42 & 0.77 \\
\hline
\end{tabular}




\section{MEASURING MODEL FIT}

\section{A.The Measurement model}

Confirmatory factor analysis (CFA) is used to assess the measurement model. Several model fit indices were assessed to identify model goodness-of-fit as recommended by Hu and Bentler [26], Hancock and Muller [27]. Six model-fit indices were used to assess the measurement model for overall goodness-of-fit namely Chi Square $\left(x^{2}\right)$, Root mean square error of approximation (RMSEA), Comparative fit index $(C F I)$, Tucker-Lewis index $(T L I)$, Standardized root mean square residuals (SRMR), Coefficient of determination $(C D)$. The model-fit statistics are presented in table IV with their recommended value.

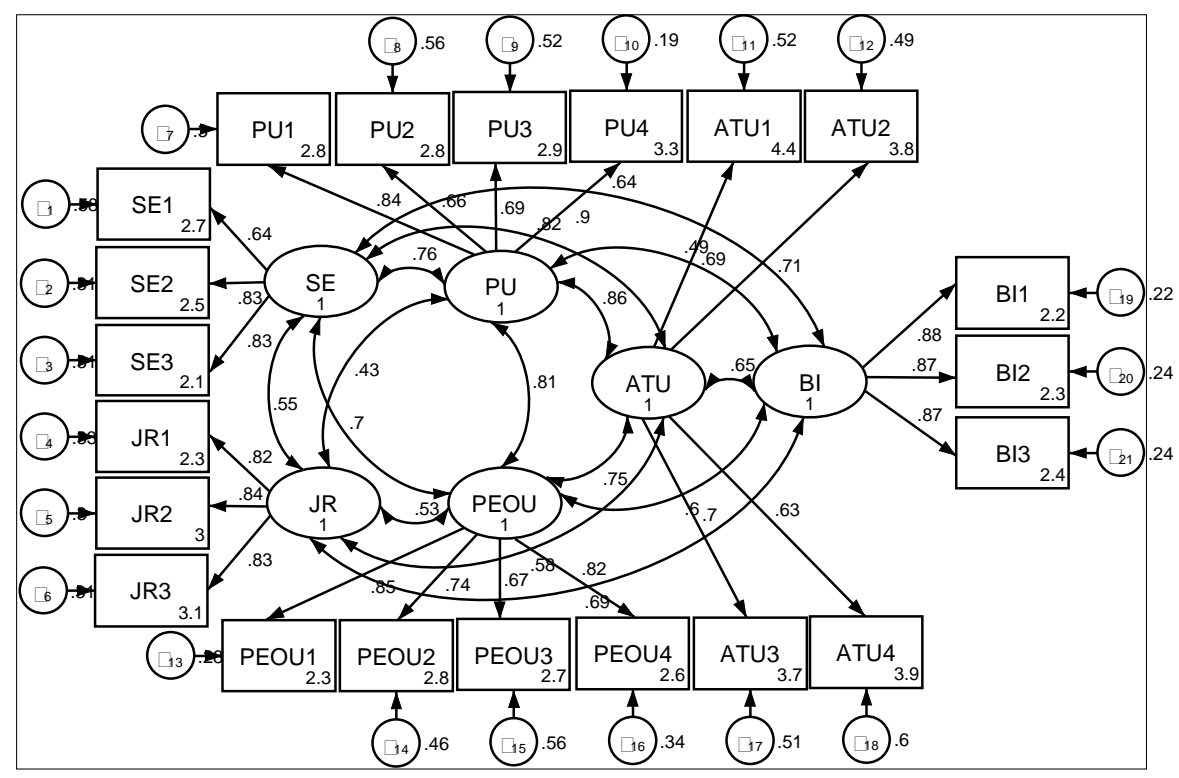

Fig. 2 Measurement model

The value of Chi Square $\left(x^{2}\right)$ with probability value is significant and the value of RMSEA is 0.093 which is greater than recommended value 0.06 , So on the basis of these two criterion we cannot accept the model. On the other hand the value of $C F I$ and $T L I$ are 0.988 and 0.965 respectively which are above the recommended value and the value of $\mathrm{CD}$ exactly 1 against the recommended value. This means that if we choose Chi Square $\left(x^{2}\right)$ and RMSEA then the model is not fitted well. Otherwise, if we choose CFI, TLI and CD the measurement model is well fitted or we can accept the model.

\section{B. The structural Model}

The common model fit indices recommended by $\mathrm{Hu}$ and Bentler[26], Hancock and Muller [27] is used to test the structural model fitness. The recommended value and the model value are presented in able 5 . It also indicate a good model fit except for Chi Square $\left(x^{2}\right)$ and RMSEA.

\section{Hypotheses Testing}

After satisfactory fit of the model, we test the structural relationship of the latent variables of the structural model. i.e studied the path coefficient of the structural model to test the hypothesis. The standardized path coefficients (Regression Coefficient), Standard error, Z-values with respective probabilities and result are summarizes in table 6.
TABLE IV FIT STATISTICS OF MEASUREMENT MODEL

\begin{tabular}{|l|c|c|}
\hline Fit indices & $\begin{array}{c}\text { Recommended } \\
\text { value [26][27] }\end{array}$ & $\begin{array}{c}\text { Model } \\
\text { value }\end{array}$ \\
\hline $\begin{array}{l}\text { Chi Square } \\
\left(\mathrm{x}^{2}\right)\end{array}$ & $\begin{array}{c}\text { Should not be } \\
\text { significant }(\mathrm{P}>0.05)\end{array}$ & $\begin{array}{c}309 \text { with } \\
\mathrm{P}=0.000\end{array}$ \\
\hline RMSEA & $<0.06$ & 0.093 \\
\hline CFI & $>0.95$ & 0.988 \\
\hline TLI & $>0.95$ & 0.965 \\
\hline SRMR & $<0.08$ & 0.063 \\
\hline CD & Close to 1 & 1 \\
\hline
\end{tabular}

TABLE V FIT STATISTICS OF STRUCTURAL MODEL

\begin{tabular}{|c|c|c|}
\hline $\begin{array}{c}\text { Fit } \\
\text { indices }\end{array}$ & $\begin{array}{c}\text { Recommended } \\
\text { value }\end{array}$ & $\begin{array}{c}\text { Model } \\
\text { value }\end{array}$ \\
\hline $\begin{array}{c}\text { Chi Square } \\
\text { (x }\end{array}$ & $\begin{array}{c}\text { Should not be } \\
\text { significant }(\mathrm{P}>0.05)\end{array}$ & $\begin{array}{c}308 \text { with } \\
\mathrm{P}=0.000\end{array}$ \\
\hline RMSEA & $<0.06$ & 0.096 \\
\hline CFI & $>0.95$ & 0.879 \\
\hline TLI & $>0.95$ & 0.857 \\
\hline SRMR & $<0.08$ & 0.066 \\
\hline CD & Close to 1 & 0.982 \\
\hline
\end{tabular}


Structural Equation Modeling for Investigating the Factors Affecting the Faculty Members Adoption and Use of E-Learning Platform in Academic Purposes: An Empirical Validation in Higher Educational Context

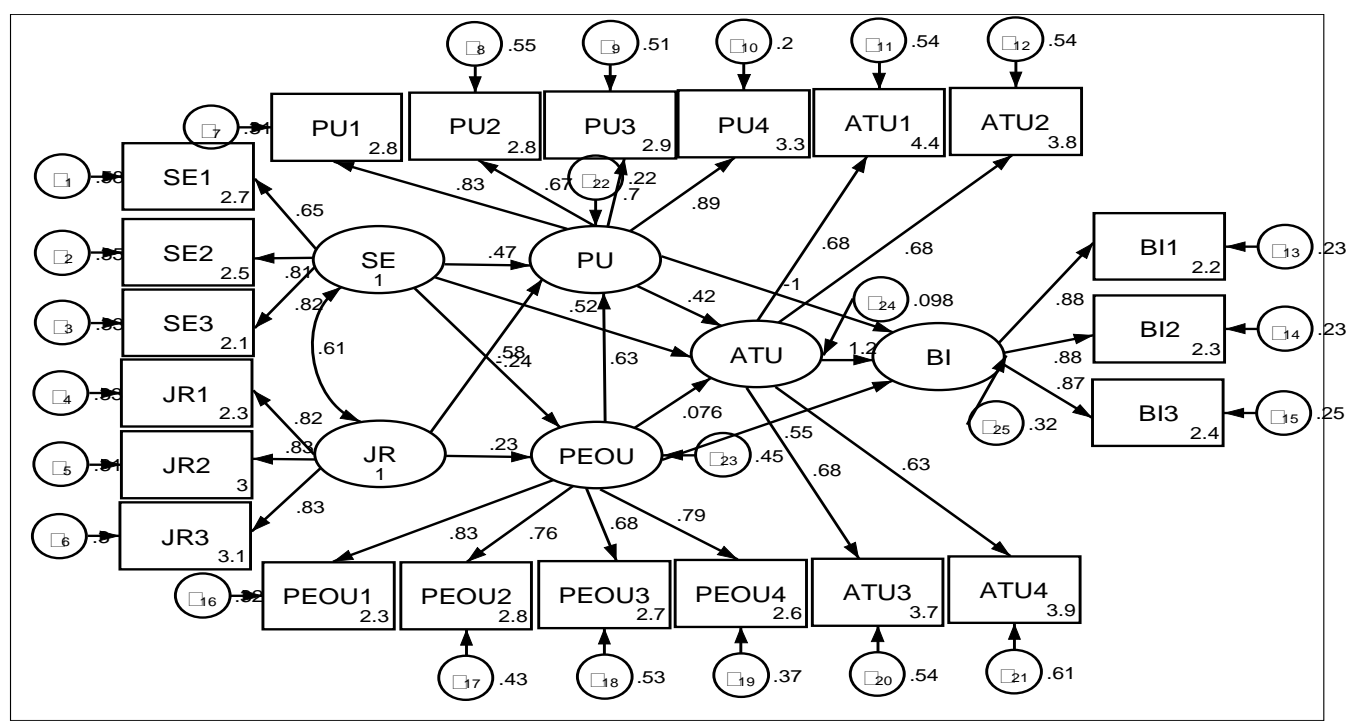

Fig. 4 The standardized structural model

TABLE V SUMMARY OF THE HYPOTHESIS TESTING (STRUCTURAL RELATIONSHIP OF LATENT VARIABLES)

\begin{tabular}{|c|c|c|c|c|c|c|}
\hline Hypothesis & Relationship & $\begin{array}{c}\text { Regression } \\
\text { Coefficient }(\boldsymbol{\beta})\end{array}$ & Standard Error & Z- statics & $\begin{array}{c}\text { Probability } \\
(\boldsymbol{P}>|\boldsymbol{Z}|)\end{array}$ & Results \\
\hline $\mathrm{H}_{1}$ & $\mathrm{BI} \leftarrow \mathrm{PU}$ & -1.01 & .50 & -2.01 & .044 & Supported \\
\hline $\mathrm{H}_{2}$ & $\mathrm{BI} \leftarrow \mathrm{PEOU}$ & .55 & .34 & 1.73 & .084 & Not Supported \\
\hline $\mathrm{H}_{3}$ & $\mathrm{BI} \leftarrow \mathrm{ATU}$ & 1.2 & .45 & 2.55 & .011 & Supported \\
\hline $\mathrm{H}_{4}$ & $\mathrm{ATU} \leftarrow \mathrm{PU}$ & .42 & .22 & 1.89 & .048 & Supported \\
\hline $\mathrm{H}_{5}$ & $\mathrm{ATU} \leftarrow \mathrm{PEOU}$ & .076 & .22 & .34 & .74 & Not Supported \\
\hline $\mathrm{H}_{6}$ & $\mathrm{PU} \leftarrow \mathrm{PEOU}$ & .63 & .15 & 4.23 & .000 & Supported \\
\hline $\mathrm{H}_{7}$ & $\mathrm{PU} \leftarrow \mathrm{JR}$ & -.24 & .12 & -1.97 & .005 & Supported \\
\hline $\mathrm{H}_{8}$ & $\mathrm{PEOU} \leftarrow \mathrm{JR}$ & .23 & .16 & 1.4 & .16 & Not Supported \\
\hline $\mathrm{H}_{9}$ & $\mathrm{PU} \leftarrow \mathrm{SE}$ & .47 & .16 & 2.82 & .005 & Supported \\
\hline $\mathrm{H}_{10}$ & $\mathrm{PEOU} \leftarrow \mathrm{SE}$ & .58 & .14 & 4.07 & .000 & Supported \\
\hline $\mathrm{H}_{11}$ & $\mathrm{ATU} \leftarrow \mathrm{SE}$ & .51 & .16 & 3.17 & .002 & Supported \\
\hline
\end{tabular}

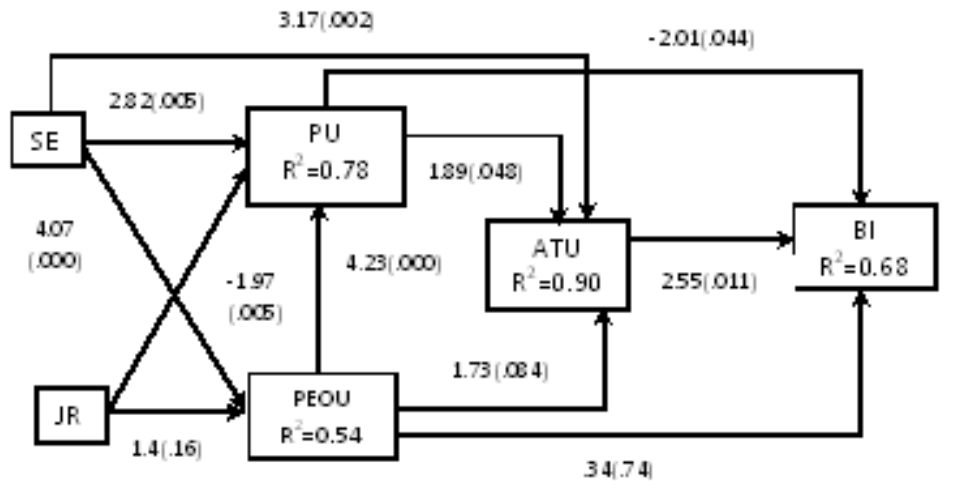

Fig. 5 The structural model estimation ((The value within bracket are the probability and $p<0.05)$ )

1. Perceived usefulness had positive effect on behavioral intention $(Z=-2.01 ; P=.004)$ to adopt and use Elearning platform in academic environment. So the hypothesis $H_{1}$ was supported. Attitude towards using had significantly positive effect on behavioral intention ( $Z=2.55 ; P=.011)$, So the hypothesis $H_{3}$ had also supported. Both the above two result are consistent with the previous studies [27][28][29][30]. On the other hand Perceived Ease of Use had no significantly positive effect on the behavioral intention ( $Z=$ $1.73 ; P=.084$ ) to adopt E-learning Platform for 
academic purposes. So the hypothesis $H_{2}$ had not supported.

2. PU had significant effect on ATU $(Z=1.89$; $P=$ .048) and it is significant with the previous result [27][29][20]. So the hypothesis $H_{4}$ was supported. SE has also significant positive effect on ATU $(Z=$ $3.17 ; P=.002$ ) towards the adoption and use of $\mathrm{E}$ learning Platform in academic purposes. So the hypothesis $H_{11}$ was supported. On the other hand PEOU had no significant effect on ATU $(Z=.34 ; P=$ .74 )on the adoption and use of E-learning Platform in academic purposes. So the hypothesis $H_{5}$ had not supported. This means that it is inconsistent with the proposed research.

3. PEOU had positively significant effect on $\mathrm{PU}(Z=$ $4.23 ; P=.00$ ) so the hypothesis $H_{6}$ was supported and this relationship is significant with the previous result[27][29][30]. On the other hand JR and SE had also positive significant on PU in adoption and use Elearning platform in academic environment as $(Z=$ $-1.97 ; P=.005)$ and $(Z=2.82 ; P=.005)$

respectively. So the hypothesis $H_{7}$ and $H_{9}$ was also supported. All these three result are consistent with the previous result [15][31][32].

4. JR had no significant positive effect on PEOU $(Z=$ 1.4; $P=.16)$. So the hypothesis $H_{8}$ had not supported. This result is consistent with those of the previous result [15][32]. On the other hand SE had significantly positive effect on PEOU $(Z=4.07 ; P=.000)$. So the hypothesis $H_{10}$ had supported. This result is also consistent with the previous result [31].

E-learning Self-Efficacy and Job Relevance Jointly explained the $78 \%$ and $54 \%$ variance of Perceived Usefulness and Perceived Ease of use respectively as shown in figure 2. Perceived Usefulness and Perceived Ease of use jointly explained $90 \%$ variance of Attitude towards Using. Perceived Usefulness, Perceived Ease of use and Attitude towards using altogether explained the $68 \%$ variance of Behavioral Intention.

\section{CONCLUSION}

This study has been done to investigated the faculty members behavioral intention to adopt and use E-learning platform in academic purposes and it validates the relationship among the core construct of TAM mainly Perceived Usefulness, Perceived Ease of Use, Attitude towards using and overall impact of behavioral intention to adopt and use E-learning Platform and we have obtained the following major findings.

Perceived usefulness and perceived ease of use are the main factors that directly affect the faculty member's attitudes and intention towards adopting and use E-learning platform in academic environment. Among the entire construct, Perceived usefulness is the strongest and most significant construct of faculty members attitude and intention to adopt and use E-learning platform in their academic purposes.
This means that the faculty members attitude and intention to adopt the system will increases if the positive feelings about the usefulness of the system increases. Some previous research result also reveals that perceived usefulness is the most strongest construct that directly affect the behavioral intentions of users to adopt and use a new system [27][28][29][30].

This current study has also incorporated two external variable namely E-learning self-efficacy and Job relevance. Job relevance was proven to be a strong relationship with TAM core construct. In particular Job relevance within the context in this study has positive influence on perceived usefulness on adoption and use E-learning platform for academic purposes. In this study it was also proven that the other external variable E-learning self-efficacy has also strong positive relationship with the core TAM construct namely Perceived Usefulness, Perceived Ease of use and Attitude towards using the E-learning Platform in academic purposes.

\section{REFERENCES}

[1] D. F. Coskuncay and S. Ozkan, "A model for instructors adoption of learning management system:Emprical validation in higher education context”, The Turkish Online Journal of Educational Technology, Vol. 12, No.2, pp. 13-25, 2003

[2] P. Moses, W.A. Ali, and S. Krauss, "Cause Analysis of Learning Management System : Role of Moderator in Improving Students Performance", Research and Practice in Technology Enhanced Learning, Vol. 9, No.1, pp. 83-105, 2014

[3] F. D. Davis, "Perceived usefulness, perceived ease of use and user acceptance of Information Technology”, MIS Quarterly: Management Information System. Vol 13, No 3, pp. 319-340, 1989

[4] H. M. Selim, "Critical success factors for e-learning acceptance. Confirmatory factor Models", Computers and Education, Vol 49, No 2, pp. 396-413, 2007

[5] B. Sumak, M. Hericko, and, M. Pusnik, "Factors affecting acceptance and use of Moodle: An empirical study based on TAM", Informatica, Vol 35, pp. 91-100, 2011

[6] D. Gefen, and D.W. Straus, "Gender difference in perception and use of E-mail: An Extension to the Technology Acceptance Model”, MIS Quarterly, Vol. 21, No 4, pp. 389-400, 1997

[7] M.S. Featherman, "Extending the Technology Acceptance Model By Inclusion of Perceived Risk", Seventh American Conferences on Information System (AMCIS), pp. 758-760, 2001

[8] D. Gefen, and E.K. Detmar,"Trust and Technology Acceptance Model in Online Shoppings: An integrated Model”, MIS Quarterly, pp. 51-90, 2003

[9] Y. Lee, J. Lee, and Z. Lee, "Social Influence on Technology Acceptance Behaviour”, ACM SIGMIS database, Vol 37, No. 2,, pp. 60-75, 2006

[10] W. M. Lim, "E-Shopping: An analysis of the Technology Acceptance Model", Published by Canadian Centre of Science and Education, Vol. 6, No 4, pp. 49-62, 2012

[11] J.K. Lee, and W.K. Lee, "The relationship of the E-learners selfregulatory efficacy and perception of E-learning environment quality”, Computer vin Human Behavior, Vol. 24, No. 5, pp. 32-47, 2011

[12] F.J. Miranda, S. Rubio, A. Chamorro and, S.C. Lourieiro, “Analuzing the use of Social Networks Sites in the Purchasing Decision Process", E-Commerce Development Implementation and Management, Doi: 10.4018/978-1-4666-9787, 2016

[13] V. Vankatesh, and F.D. Davis, "A Model of the Antecedents of Perceived Ease of Use: Development and Trust”, Decesion Science, pp. 451-481, 1996

[14] R.B. Schafer, and J. L. Tait, "A Guide for Understanding Attitudes and Attitudes Change", [AMES]: [Cooperative Extension Service, Iowa State University], 1986 
Structural Equation Modeling for Investigating the Factors Affecting the Faculty Members Adoption and Use of E-Learning Platform in Academic Purposes: An Empirical Validation in Higher Educational Context

[15] R.C. King, and M.L. Gribbins, "Internet Technology Adoption an Organizational event : An Exploratory Study Across Industries”, System Science. HICSS. Proceddings of $35^{\text {th }}$ Annual Hawaii International Conference. pp. 2683-2692, 2002

[16] M. Wu, H. Chou, Y. Weng, and Y. Huang, "TAM2-based study of Website User Behavior - Using Web 2.0 Website as an Example”, Wseas Transactions on Business and Economics, Vol. 4, No. 8, pp. 133-151, 2011

[17] V. Venkatesh, and F.D. Davis, "A Theoretical Extension of the Technology Acceptance Model”, Four Longitudinal Field Studies, Management Science, Vol. 46, No.2, pp. 186-204, 2000

[18] Bandura, "Self-efficacy. In V.S Ramachaudran", Encyclopedia of human behavior, Vol. 4, pp. 71-81, 1994

[19] N. Fathema, D. Shannon, and M. Ross, "Expanding The Technology Acceptance Model (TAM) to Examine Faculty Use of Learning Management Systems (LMSs) In Higher Education Institutions”, MERLOT Journal of Online Learning and Teaching, Vol. 11, No. 2, pp. 210 - 2015, 2015

[20] J.W. Lee and S. Medlinger, "Perceived Self-Efficiacy and Its Effect on Online Learning Acceptance and Students Satisfication”, Journal ofService Science and Management , pp. 243 - 252, 2011

[21] S.Y. Park, "An analysis of the technology acceptance model in understanding university students behavioral intention to use Elearning”, Educational Technology \& Science, Vol. 12, No. 3, pp. $150-162,2009$

[22] D. K. Maduku, "Behavioral intention towards mobile banking usage by South Africa retail banking clients", Investment Management anf financial innovations, Vol. 11, No. 3, pp. 58-72, 2014

[23] S. Taylor, and P. A. Tood, "Understanding Information Technology Usage: A test of competing models", Information System Research, Vol. 6, No. 2, pp. 144-176, 1995

[24] C. Fornell, and D. F. Larcker, "Evaluating structural equation models with unobservable variables and measurement error", Journal of Marketing Research, Vol. 18, No. 1, pp. 39-50, 1981
[25] N. Schmitt, "Uses and abuses of Coefficient alpha", Psychological Assessment, Vol. 8, pp.-350-353, 1996

[26] L.T. Hu, and P.M. Bentler, "Cutoff Criteria for fit indexes in covariance structure analysis: Conventional criteria versus new alternatives”, Structural Equation Modeling, Vol. 6, No. 1, pp. 1-55, 1999

[27] G.R. Hancock, and R.O. Mueller, "Structural Equation Modeling: A second course. Charlotte, NC" Information age publishing, Vol. 2, pp. 439-492, 2006

[28] [28] O. Micholas, A. Azeta, I. Chiazor, and N. Omoregbe, "Predecting the adoption of E-learning Management System: A case of selected private universitiesin Nigeria", Turkish Online Journal of Distance Education , Vol. 18, No. 2, pp. 106-121, 2017

[29] M. Masrom, “Technology Acceptance Model and E-learning”, $12^{\text {th }}$ International conference on education, Sultan HassanalBolkiah institute of education, 2007.

[30] Adwan, and J. Somedly, "Exploring students acceptance of Elearning using Technology Acceptance Model in Jordanian Universities", International Journal of Education and Development using Information and Communication Technology, Vol. 9, No. 2, pp. 4-18, 2013

[31] N. Fathema, D. Shannon, and M. Ross, "Extending the technology acceptance model (TAM) to examine faculty use of LMS in Higher education institution", MERLOT Journal of online learning and teaching, Vol. 11, No. 2, pp. 210-132, 2015

[32] S. Alharbi, and S. Drew, "Using the technology acceptance model in understanding academics behavioural intention to use LMS", International Journal of Advanced Computer Science and Application, Vol. 5, No. 1, pp. 143-155, 2014. 